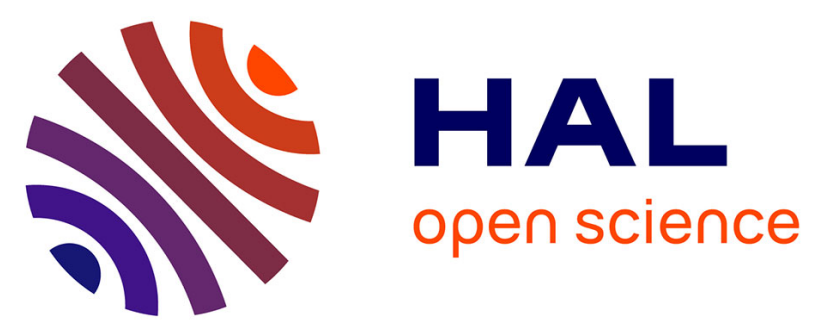

\title{
Two-dimensional copper (II) halide-based hybrid perovskite templated by 2-chloroethylammonium Crystal structures, phase transitions, optical and electrical properties
}

F. Akrout, F. Hajlaoui, K. Karoui, Nathalie Audebrand, Thierry Roisnel, N. Zouari

\section{To cite this version:}

F. Akrout, F. Hajlaoui, K. Karoui, Nathalie Audebrand, Thierry Roisnel, et al.. Two-dimensional copper (II) halide-based hybrid perovskite templated by 2-chloroethylammonium Crystal structures, phase transitions, optical and electrical properties. Journal of Solid State Chemistry, 2020, 287, pp.121338. 10.1016/j.jssc.2020.121338 . hal-02569956

\section{HAL Id: hal-02569956}

https:/ / hal-univ-rennes1.archives-ouvertes.fr/hal-02569956

Submitted on 20 May 2020

HAL is a multi-disciplinary open access archive for the deposit and dissemination of scientific research documents, whether they are published or not. The documents may come from teaching and research institutions in France or abroad, or from public or private research centers.
L'archive ouverte pluridisciplinaire HAL, est destinée au dépôt et à la diffusion de documents scientifiques de niveau recherche, publiés ou non, émanant des établissements d'enseignement et de recherche français ou étrangers, des laboratoires publics ou privés. 


\section{Graphical Abstract}
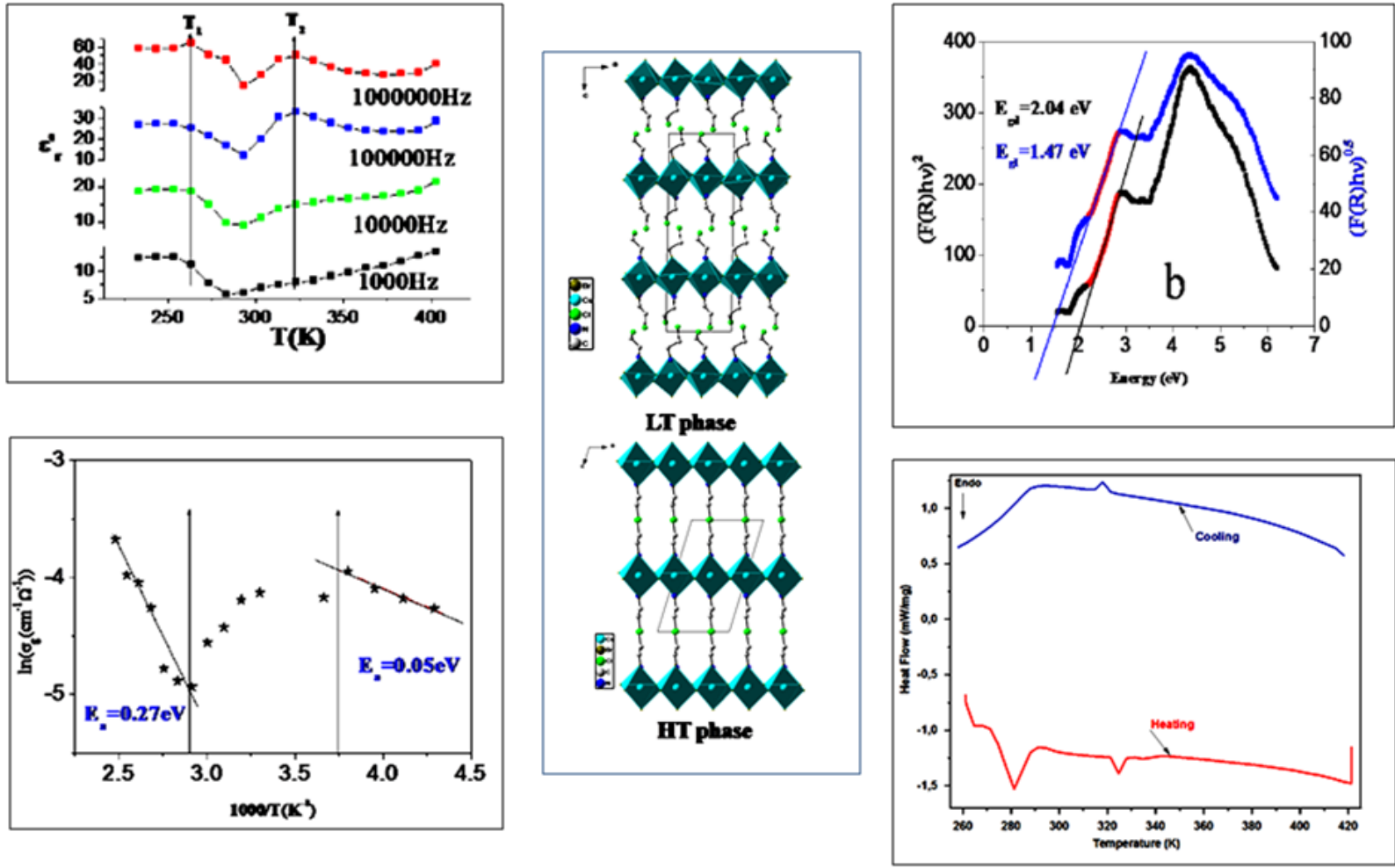


\title{
Two-Dimensional Copper (II) Halide-Based Hybrid Perovskite Templated by 2-Chloroethylammonium: Crystal Structures, Phase Transitions, Optical and Electrical Properties
}

\author{
Farah Akrout ${ }^{1}$, Fadhel Hajlaoui* ${ }^{1}$, Karim Karoui ${ }^{2}$, Nathalie Audebrand ${ }^{3}$, Thierry Roisnel ${ }^{3}$, Nabil \\ Zouari $^{1}$ \\ ${ }^{1}$ Laboratoire Physico-chimie de l'Etat Solide, Département de Chimie, Faculté des Sciences de \\ Sfax, B.P. 1171, 3000 Sfax, Université de Sfax, Tunisia \\ ${ }^{2}$ Laboratoire des caractérisations spectroscopiques et optique des matériaux, Faculté des Sciences \\ de Sfax, B.P. 1171, 3000 Sfax, Université de Sfax, Tunisia \\ ${ }^{3}$ Univ Rennes, CNRS, ISCR (Institut des Sciences Chimiques de Rennes) - UMR 6226, F-35000 \\ Rennes, France
}

Corresponding Authors E-mail: fadhelh83@yahoo.fr (Hajlaoui Fadhel)

\begin{abstract}
Hybrid inorganic-organic perovskites attracted increasing attention because of variety of their applications in the fields of photovoltaics, photoelectronics and switchable dielectric devices. Diverse molecular functional materials can be assembled by modifying the length of the organic components and inorganic framework dimensionality and, thus, they might be promising candidates to obtain phase-transition materials. In this study, we present a new hybrid perovskite-like compound, $\left(\mathrm{ClC}_{2} \mathrm{H}_{4} \mathrm{NH}_{3}\right)_{2} \mathrm{CuBr}_{4}$ (I), which follows the two-dimensional inorganic frameworks of the corner-sharing $\mathrm{CuBr}_{6}$ octahedra. Strikingly, compound (I) displays a dielectric phase transition at around $275 \mathrm{~K}$, changing from the non-centrosymmetric space group of $P c$ (LT phase) to centrosymmetric $P 2{ }_{1} / a$ (HT phase) upon heating. The crystal structure analyses reveal that the unusual thermally activated conformation change of the 2-chloroethylammonium cations and distortions of $\mathrm{CuBr}_{6}{ }^{4-}$ network in the inorganic layers afford the driving force to the phase transition. Moreover, the Jahn-Teller distortion introduces elongation of coordination bonds in the inorganic planes, which confers higher flexibility to the structure. Compound (I) displays phase transitions at $\mathrm{T}_{1}=270 \mathrm{~K}$ and $\mathrm{T}_{2}=323 \mathrm{~K}$, confirmed by DSC measurements. In addition, the UV/Vis optical spectrum indicates that (I) has an indirect band gap of $1.47 \mathrm{eV}$. This finding may extend the application of 2D layered lead-free hybrid perovskite-type materials to the field of photovoltaic as the photo absorber layer of solar cells.
\end{abstract}


Keywords: Hybrid perovskites, phase transition, Crystal structure, semiconductor material.

\section{Introduction}

Recently, the phase transition materials have drawn great interest because of their applications in data storage, ${ }^{[1]}$ ferroelectrics, ${ }^{[2]}$ thermochromic smart windows, ${ }^{[3]}$ photovoltaic stream, ${ }^{[4]}$ optoelectronic properties ${ }^{[5]}$ and various other applications ${ }^{[6-9]}$. Various approaches have been developed to prepare the phase transition materials. Among them, the synthesis of organic-inorganic compounds, which are able to combine desirable characteristics from both types of constituents, is one of the most effective methods. ${ }^{[10-11]}$ Particularly, the layered hybrid materials are extensively investigated in view of their interesting structural phase transitions ${ }^{[12-13]}$. The recent studies shown that the main structural features of these layered materials are the inorganic layers alternated with organic cations and that there are hydrogen-bonding interactions between the organic and inorganic molecules. Meanwhile, reorientation of the organic cations and deformation of the anionic framework were shown to easily induce the phase transitions and consequently generate very promising properties. ${ }^{[14-15]}$ Very recently, the hybrid perovskite materials with diversified structures received increasing interest owing to a variety of intriguing properties, ranging from phase transitions, ferroelectric, dielectric, optical to thermochromic properties. ${ }^{[16-17]}$ In these valuable works, the introduction of organic moieties with a flexible structure has been conceived as an effective strategy to construct new molecular phase transition systems.

For instance, layered halide perovskite-like compounds (4-methylpiperidinium) $\mathrm{CdCl}_{3}{ }^{[18]}$ and $\left(\mathrm{C}_{4} \mathrm{H}_{9} \mathrm{NH}_{3}\right)_{2} \mathrm{PbBr}_{4}{ }^{[19]}$ with a $1 \mathrm{D}$ and $2 \mathrm{D}$ structures, respectively, display sequential structural phase transitions associated with the motion of the organic cation. Moreover, ferroelectric transitions, dielectric and optical properties have been identified in crystals of (pyrrolidinium) $\mathrm{MnX}_{3}(\mathrm{X}=\mathrm{Cl}$ or $\mathrm{Br})^{[20]}$ and (1,5-diaminopentane) $\mathrm{MnCl}_{4},{ }^{[21]}$ including potential switchable dielectric behaviours, which originated from the dynamic disordering of organic cations. In addition, the copper-based organic-inorganic hybrid halides were reported with promising ferroelectric character and, more importantly, they shown abundant phase transitions and thermochromic properties. Given the diversity of structural networks and properties attainable with copper halides, we cite here the 2D layered hybrid compound $\left(\mathrm{C}_{6} \mathrm{H}_{5} \mathrm{CH}_{2} \mathrm{NH}_{3}\right)_{2} \mathrm{CuBr}_{4}{ }^{[22]}$, which demonstrates prominent semiconductor character and presents photovoltaic properties. 
Additionally, many numerous organic-inorganic halide perovskites $\left[\mathrm{NH}_{3}-\left(\mathrm{CH}_{2}\right)_{4}-\mathrm{NH}_{3}\right] \mathrm{CuCl}_{4}{ }^{[23]}$ and $\left[2,2^{\prime}\right.$-(ethylenedioxy)bis-(ethylammonium) $] \mathrm{CuCl}_{4}{ }^{[24]}$ were shown to be sensitive to the pressure.

Additionally, many numerous organic-inorganic halide perovskites $\left[\mathrm{NH}_{3}-\left(\mathrm{CH}_{2}\right)_{4}-\mathrm{NH}_{3}\right] \mathrm{CuCl}_{4}{ }^{\text {[23] }}$ and $\left[2,2^{\prime}\right.$-(ethylenedioxy)bis-(ethylammonium) $] \mathrm{CuCl}_{4}{ }^{[24]}$ were shown to be sensitive to pressure. Indeed, under pressure, the $\mathrm{Cu}$ compounds exhibit yellow to black piezochromism, insulator to semiconductor transition and increase in electrical conductivity. The $\mathrm{Cu}$ atoms in $\mathrm{Cu}-\mathrm{Cl}$ perovskites are Jahn-Teller active that generates octahedra tilting and elongation in the axial $\mathrm{Cu}-\mathrm{Cl}$ bonds. These kinds of properties make copper based halide perovskites to be among the best candidates for designing multifunctional materials. Herein, in the process of exploring the solidsolid phase transition materials, we have reported an organic-inorganic hybrid perovskite-type compound (I) $\left(\mathrm{ClC}_{2} \mathrm{H}_{4} \mathrm{NH}_{3}\right)_{2} \mathrm{CuBr}_{4}$, which belongs to the typical two-dimensional perovskite-like structure. The DSC measurements, structural analyses at various temperatures, dielectric measurements and impedance spectroscopy were performed to investigate the phase transitions and electric properties. From the structural analysis, we infer that the phase transition of (I) results from the conformation changes of organic cations along with the reorientation of $\mathrm{CuBr}_{6}$ polyanionic zigzag chains, arising from Jahn-Teller distortion. The structural phase transition observed in compound (I) at around $270 \mathrm{~K}$ is induced by an unusual conformation variation of 2chloroethylammonium cations namely a chairlike-to-boatlike change of the spatial conformation. The latter can influence this structural change as they are attached to the inorganic framework via hydrogen bonding interactions. In this regard, the modification of organic cations may provide deep insights into the phase transition as well as an effective way to achieve the best performance from hybrid perovskites. Besides, compound (I) exhibits semiconducting behaviour with a bandgap (Eg) of $\sim 1.47 \mathrm{eV}$, comparable with those observed in $\left[\left(\mathrm{C}_{6} \mathrm{H}_{5} \mathrm{CH}_{2} \mathrm{NH}_{3}\right)_{2} \mathrm{CuBr}_{4}\right]\left(\mathrm{E}_{\mathrm{g}}=1.81 \mathrm{eV}\right){ }^{[22]}$, [(p-F$\left.\left.\mathrm{C}_{6} \mathrm{H}_{5} \mathrm{C}_{2} \mathrm{H}_{4}-\mathrm{NH}_{3}\right)_{2} \mathrm{CuBr}_{4}\right]\left(\mathrm{E}_{\mathrm{g}}=1.74 \mathrm{eV}\right){ }^{[25]}$ and $\left(\mathrm{CH}_{3}\left(\mathrm{CH}_{2}\right)_{3} \mathrm{NH}_{3}\right)_{2} \mathrm{CuBr}_{4}\left(\mathrm{E}_{\mathrm{g}}=1.76 \mathrm{eV}\right) .{ }^{[25]}$ These findings throw light on the further research of dielectric phase transition materials based on copper bromide hybrid organic-inorganic compounds.

\section{Experimental Section}

\subsection{Synthesis}

The analytical grade chemicals were used without any further purification for the synthesis and were purchased from Aldrich. Crystals of $\left(\mathrm{ClC}_{2} \mathrm{H}_{4} \mathrm{NH}_{3}\right)_{2} \mathrm{CuBr}_{4}$ were synthesized by liquid-gaz low diffusion method. Copper bromide $(1 \mathrm{mmol})$ was first dissolved into hydrobromic acid $(6 \mathrm{~mL})$, in which $\mathrm{NH}_{2}\left(\mathrm{CH}_{2}\right)_{2} \mathrm{Cl}^{\cdot} \mathrm{HCl}(2 \mathrm{mmol})$ was added in a second step. The solution, which was first stirred during a few minutes at room temperature until complete dissolution, was placed into a saturated acetone vapor atmosphere. After less than one hour, the intense black crystals were collected by filtration and washed rapidly with cold ethyl acetate. The purity of the compound was confirmed by 
an elemental microanalysis: Anal. (Calcd): C, $9.83 \%(8.81 \%) ; \mathrm{H}, 3.02 \%(2.57 \%) ; \mathrm{N}, 5.73 \%$ (5.14\%). Yield: $82.6 \%$ based on $\mathrm{Cu}$. The IR-spectrum measured at room temperature of $\left(\mathrm{ClC}_{2} \mathrm{H}_{4} \mathrm{NH}_{3}\right)_{2} \mathrm{CuBr}_{4}$ shows at high wavenumbers an absorption centered at 3115, 3094 and 2995 $\mathrm{cm}^{-1}$ correspond respectively to the asymmetric and symmetric vibrations of the $\mathrm{NH}$ stretching bands. The band of $\left(-\mathrm{CH}_{2}-\right)$ appears around $1391 \mathrm{~cm}^{-1}$, whereas the absorption band of C-N group appears at $925 \mathrm{~cm}^{-1}$. The band at $763 \mathrm{~cm}^{-1}$ is assigned to the $\mathrm{C}-\mathrm{Cl}$ stretching vibration (Figure $\mathrm{S} 1$ ). The assignments of the most relevant modes associated with vibrations of (I) are mentioned in Table S1. In addition, the CP MAS ${ }^{13} \mathrm{C}$ solid-state NMR experiments were carried out at room temperature. The experiments on the starting material $\left(\mathrm{ClC}_{2} \mathrm{H}_{4} \mathrm{NH}_{3}\right)_{2} \mathrm{CuBr}_{4}$ (I) (Figure S2) were carried out allowing the determination of the isotropic chemical shift values of the $\mathrm{H}_{2} \mathrm{C}-\mathrm{Cl}, \mathrm{H}_{2} \mathrm{C}$ $\mathrm{NH}_{3}$ and $\mathrm{Cu}$ atoms: ${ }^{13} \mathrm{C} \mathrm{NMR}: \delta=56.00\left(\mathrm{~d}, \mathrm{H}_{2} \mathrm{C}-\mathrm{NH}_{3}\right)$ and $\delta=109.14\left(\mathrm{~d}, \mathrm{H}_{2} \mathrm{C}-\mathrm{Cl}\right)$ ppm while, in the ${ }^{63} \mathrm{Cu}$ NMR, $\delta=2301.27 \mathrm{ppm}$.

\subsection{Thermal measurements}

The differential scanning calorimetry (DSC) analyses of compound 1 (5.12 $\mathrm{mg}$ ) were performed using a Perkin-Elmer DSC instrument in the temperature ranges of $240-440 \mathrm{~K}$. The crystalline samples were placed in aluminum crucibles that were heated (cooled) at scanning rate $\left(5 \mathrm{~K} \cdot \mathrm{min}^{-1}\right)$ under flowing nitrogen at atmospheric pressure. The thermogravimetric Analysis (TGA) and the Differential Thermal Analysis (DTA) were performed using a Setaram SETSYS 16/18 instrument in the temperature range of $298-973 \mathrm{~K}$ with a ramp rate of $5 \mathrm{~K} \mathrm{~min}^{-1}$.

\subsection{Single Crystal Structure Determination}

The single-crystal X-ray diffraction data of $\left(\mathrm{ClC}_{2} \mathrm{H}_{4} \mathrm{NH}_{3}\right)_{2} \mathrm{CuBr}_{4}(\mathbf{I})$ crystals were collected at $150 \mathrm{~K}$ (LT Phase: low-temperature phase) on a D8 VENTURE Bruker AXS diffractometer and processed with the APEX 3 program suite. ${ }^{[26]}$ The structure of LT phase was refined as a pseudo-merohedral twin with twin matrix -1 $0000-100.09201$. Meanwhile, for the same compound (I), the data were collected at $293 \mathrm{~K}$ (HT Phase: high-temperature phase) on an APEX-II Bruker AXS diffractometer and processed with the APEX 2 program suite. ${ }^{[27]}$ The used X-ray wavelength was the Mo-K $\alpha$ radiation $(\lambda=0.71073 \AA)$. The frame integration and data reduction were carried out with the program SAINT. ${ }^{[28]}$ The program SADABS $^{[29]}$ was employed for multiscan-type absorption corrections. The crystal structures were solved by direct methods and dual space methods using the SHELXT software package, ${ }^{[30]}$ and refined with full-matrix least-square methods based on $\mathrm{F}^{2}$ (SHELXL-2014) ${ }^{[31]}$ through the WinGX program suite. ${ }^{[32]}$ All non-hydrogen atoms were anisotropically refined, and the positions of $\mathrm{H}$-atoms were geometrically assigned and allowed to ride on their parent atoms, with $\mathrm{C}-\mathrm{H}=0.97 \AA$ and $\mathrm{N}-\mathrm{H}=0.89 \AA$. The software Diamond ${ }^{[33]}$ was used to create the graphic representations of the crystal structures. The details of crystallographic 
data and structure refinements at 150 and $293 \mathrm{~K}$ are listed in Table $\mathrm{S} 2$. The related selected bond lengths and angles are summarized in Tables S3-S6.

\subsection{Ultraviolet-visible (UV-vis) Absorption spectrum}

The ultraviolet-visible (UV-vis) diffuse reflectance spectrum of $\left(\mathrm{ClC}_{2} \mathrm{H}_{4} \mathrm{NH}_{3}\right)_{2} \mathrm{CuBr}_{4}$ (I) was measured at room temperature using a Shimadzu-type 3101PC UV spectrophotometer equipped with a double-beam monochromator covering the spectrum range from $200 \mathrm{~nm}$ to $800 \mathrm{~nm}$ with two sources: (i) xenon lamp for the UV-Visible domain, (ii) halogen lamp for the infrared range. This technique allows determining the absorbance (A) and reflectance (R) of material (I). The powdered crystals of $\left(\mathrm{ClC}_{2} \mathrm{H}_{4} \mathrm{NH}_{3}\right)_{2} \mathrm{CuBr}_{4}(\mathbf{I})$ were used for the measurements.

\subsection{Electrical measurements}

The real and imaginary components ( $Z^{\prime}$ and $\left.Z^{\prime \prime}\right)$ of impedance were measured on pellet disks of about $8 \mathrm{~mm}$ in diameter and $1.2 \mathrm{~mm}$ in thickness over the frequency range of $1-10^{6} \mathrm{~Hz}$ with a SOLARTRON SI 1260 impedance equipment coupled to a dielectric interface in the temperature range of $223-413 \mathrm{~K}$.

\section{Results and discussion}

\subsection{Thermal properties}

Since this type of compounds is prone to phase transitions, ${ }^{[19,21,22,34]}$ we examined their thermal stability by DSC and TGA measurements. First, the DSC measurement was performed to detect the phase transition behavior of $\left(\mathrm{ClC}_{2} \mathrm{H}_{4} \mathrm{NH}_{3}\right)_{2} \mathrm{CuBr}_{4}$. As shown in Figure 1, during the heating and cooling cycles, two sequential phase transitions were observed at $270 \mathrm{~K}$ and $323 \mathrm{~K}$. Moreover, the compound $\left(\mathrm{ClC}_{2} \mathrm{H}_{4} \mathrm{NH}_{3}\right)_{2} \mathrm{CuBr}_{4}$ is thermally stable up to $\sim 433 \mathrm{~K}$, and the phase transitions $\left(\mathrm{T}_{1}=\right.$ $270 \mathrm{~K}$ and $\mathrm{T}_{2}=323 \mathrm{~K}$ ) are far away from its decomposition point, as seen in the TGA curve shown in Figure S3. Such kind of large temperature-interval demonstrates the high thermal stability of compound (I), which provides the possibility to adjust the Tc of materials to room temperature and broaden their applications.

\subsection{Single Crystal Structure Analysis}

To explore the microscopic mechanism of structural transformation, the single-crystal X-ray diffraction structural analysis of $\left(\mathrm{ClC}_{2} \mathrm{H}_{4} \mathrm{NH}_{3}\right)_{2} \mathrm{CuBr}_{4}$ was carried out at two different temperatures, i.e., $150 \mathrm{~K}$ and $293 \mathrm{~K}$, related to LT- (low temperature phase) and HT-phase (high-temperature phase), respectively. The results indicate that $\left(\mathrm{ClC}_{2} \mathrm{H}_{4} \mathrm{NH}_{3}\right)_{2} \mathrm{CuBr}_{4}$ crystallizes in monoclinic system with different space groups: non centrosymmetric group $P c$ in LT phase and centrosymmetric space group $\mathrm{P} 2{ }_{1} / a$ in HT phase. The cell parameters for HT phase are $a=7.9213$ (7) $\AA, b=7.6524$ (7) $\AA$, $c=12.4539(15) \AA, \beta=107.003(7)^{\circ}, V=721.92(13) \AA^{3}$ and $Z=2$, while for LT phase, the cell parameters are $a=7.6224(10) \AA, b=7.8983(9) \AA, c=23.224(3) \AA, \beta=90.864(5)^{\circ}, V=1398.0(3)$ 
$\AA^{3}$ and $Z=2$. The crystal data for LT phase and HT phase are reported in Table S2. The difference in the crystal structures between LT phase and HT phase can be easily understood from the microscopic structural changes of compound (I) during its phase transition. The asymmetric unit of (I) at LT phase consists of four 2-chloroethylammonium cations and two independent $\mathrm{CuBr}_{4}{ }^{2-}$ anions, while asymmetric unit for HT phase attains one 2-chloroethylammonium cation and half a $\mathrm{CuBr}_{4}{ }^{2-}$ anion (Figure S4). The $\mathrm{CuBr}_{4}{ }^{2-}$ ions is distorted as two of the six $\mathrm{Cu}-\mathrm{Br}$ bonds of the copper ion are longer than the others due to Jahn-Teller elongation of coordination bonds. The intermolecular and intramolecular H-bonding distances are given in Figure S4. In addition, the 2chloroethylammonium cation resembles a chair like and boat like at LT phase. However, it transforms into a chair like when the temperature rises to HT phase, that is, (I) undergoes a chair-toboat conformation transformation during its phase transition, which differs from the order-disorder mechanism often encountered in hybrid metal-halide perovskites. ${ }^{[21,35,36]}$

The HT phase of (I) crystallizes in the monoclinic space group $\mathrm{P} 2_{1} / a$, and the crystal packing features the corner-sharing $\mathrm{CuBr}_{6}{ }^{4-}$ infinite anionic chains expending along the b-axis (Figure 2 (c)). The coordination of $\mathrm{Cu}^{2+}$ is completed by sharing two chlorine atoms from adjacent $\mathrm{CuBr}_{4}{ }^{2-}$ ions, forming a 2D layer. The organic cation occupies the voids of octahedral anionic chains through N$\mathrm{H} \cdots \mathrm{Br}$ hydrogen bondings with bridging $\mathrm{Br}$ atoms of two adjacent anionic chains (Figure 2 (d)).

Due to the Jahn-Teller effect, the octahedra in the inorganic sheet are distorted. Indeed, the value of $\mathrm{Cu} 1-\mathrm{Br}-\mathrm{Cu} 1$ bond angles is $166.7^{\circ}$ and the angle of the zigzag chain is $87.48^{\circ}$ (Figure 3 ). Additionally, the $\mathrm{Br}-\mathrm{Cu} 1-\mathrm{Br}$ bond angles vary from $89.89^{\circ}$ to $90.11^{\circ}$ and the bond lengths in the $\mathrm{CuBr}_{6}$ octahedra vary from 2.411 to $3.123 \AA$, evidencing the distorted octahedron coordination geometry. These angles and average bond length are comparable to those of structurally similar reported 2D Cu-based hybrid perovskites, such as: $\left(\left(\mathrm{CH}_{3} \mathrm{NH}_{3}\right)_{2}\right) \mathrm{CuCl}_{\mathrm{x}} \mathrm{Br}_{4-\mathrm{x}}$, [37] $\left(\mathrm{C}_{24} \mathrm{H}_{22} \mathrm{~N}_{2} \mathrm{O}_{3}\right) \mathrm{CuCl}_{4},{ }^{[38]}$ and $\left(\mathrm{NH}_{3}-\left(\mathrm{CH}_{2}\right)_{4}-\mathrm{NH}_{3}\right) \mathrm{CuCl}_{4} \cdot{ }^{[39]}$ The adjacent $\mathrm{Cu} \cdots \mathrm{Cu}$ distance $(5.507 \AA)$ is comparable with that observed in $\left(\mathrm{C}_{6} \mathrm{H}_{5} \mathrm{CH}_{2} \mathrm{CH}_{2} \mathrm{NH}_{3}\right)_{2}\left[\mathrm{CuCl}_{4}\right],(5.210 \AA)^{[2]}$.

For the 2-chloroethylammonium cation of (I) its HT phase, the atoms of N1 and $\mathrm{Cl}$ are situated below and above the coplanar conformations, respectively, behaving as a chair-like conformation.

The organic cations link the inorganic framework by weak hydrogen bonding $\mathrm{N}-\mathrm{H} \cdots \mathrm{Br}$ interactions with distances varying from 3.389 to $3.724 \AA$ (Table S4).

The LT phase of (I) has a packing structure similar to that of the HT phase (Figure 2(a)). It is worth mentioning that the space group drops to $P c$ with a decrease in temperature, and the cell parameters are also changed (Table S2). The molecular structure of LT phase can be considered as copper bromide layered organic-inorganic perovskite-like configuration, containing infinite octahedra corner-sharing $\mathrm{Cu}_{1} \mathrm{Br}_{6}$ and $\mathrm{Cu}_{2} \mathrm{Br}_{6}$ layers, which extend along the $a$ and $c$ axes with the shortest 
Cu1...Cu2 distance of $5.476 \AA$. The 2-chloethylammonium cations reside in the cavities produced by the anionic chains through $\mathrm{N}-\mathrm{H} \cdots \mathrm{Br}$ hydrogen bonding, as displayed in Figure 2(b).

At LT phase, the molecular conformation of organic cations displays an evident change. Indeed, some atoms move to the same side of the coplanar and others of N1 (or N2) and Cl1 (or Cl2) are situated below and above the coplanar conformations. Consequently, the structure of the 2chloroethylammonium cation changes from a boat-like to a chair-like configuration. As depicted in Figure 3, the values of $\mathrm{Cu}-\mathrm{Br}-\mathrm{Cu}$ bond angle are $159.8^{\circ}$ and $169^{\circ}$, while, the bond angles of zigzag chains are $89.47^{\circ}$ and 89.72 . The $\mathrm{Br}-\mathrm{Cu}-\mathrm{Br}$ bond angles and the $\mathrm{Cu}-\mathrm{Br}$ bond lengths vary from $89.2^{\circ}$ to $91.2^{\circ}$ and 2.403 to $3.175 \AA$, respectively, which exhibits some changes in comparison with the values in HT phase (see Tables S3-S4). The organic cations and $\mathrm{CuBr}_{6}{ }^{4-}$ are bonded through weak hydrogen bonds $(\mathrm{N}-\mathrm{H} \cdots \mathrm{Br})$, for which the donor-acceptor distances are in the range of 3.15$3.91 \AA$ (Table S6). The H-bond lengths values are similar to those observed in other $\left(\mathrm{C}_{\mathrm{n}} \mathrm{H}_{2 \mathrm{n}+1} \mathrm{NH}_{3}\right)_{2} \mathrm{MX}_{4}$ perovskites-like (where $\mathrm{n}=1,2, \ldots ; \mathrm{M}$ is a transition metal; and $\mathrm{X}$ is a halogen). ${ }^{[37,40]}$

The above discussed single-crystal X-ray diffraction studies reveal that the 2-chloroethylammonium cations of compound (I) undergoes exceptional chair to boat conformation transformation during its phase transition. The latter is in close relation with the distortion of $\mathrm{CuBr}_{6}{ }^{4-}$ layer and consequently the coordination environment of copper ions. In addition, the central copper (II) atoms of $\mathrm{CuBr}_{6}$ octahedra are coordinated by six bromide atoms, two of which behaving as bridging linkers. As a result, two $\mathrm{CuBr}_{6}$ octahedra share two bridging corners ( $\mathrm{Br} 3$ and $\mathrm{Br} 8$ at $\mathrm{LT}$ phase or $\mathrm{Br} 2$ and $\mathrm{Br} 2 "$ at $\mathrm{HT}$ phase), and the corner-sharing $\mathrm{CuBr}_{6}$ octahedra construct a 2D perovskite-derivative inorganic framework (Figure 2(e)). As a result, it is deduced that the phase transition of (I) is related to the conformational changes of the organic cations and the reorientational displacement of $\mathrm{CuBr}_{6}{ }^{4-}$ anionic chains influenced by the Jahn-Teller effect.

\subsection{Optical properties of compound (I)}

The optical properties of this compound were investigated using diffuse absorbance and reflectance spectroscopy. As shown in Figure 4 (a), three peaks at 290, 430 and 589nm are observed in the absorption spectrum. Among these peaks, the strongest absorbance observed for the peak at 430nm indicate that this peak corresponds of the transition from valence to conduction band, where is due to the charge transfer 'ligand_metal' $(4 \mathrm{p} \mathrm{Br} \rightarrow 3 \mathrm{~d} \mathrm{Cu}) .{ }^{[41]}$ The two other peaks at 290 and $691 \mathrm{~nm}$ can be due to a photoinduced exciton formed in the inorganic $\mathrm{CuBr}_{4}{ }^{2-}$ complexes. ${ }^{[37]}$ The diffuse reflectance data measured in the UV-vis range were transformed to pseudo-absorption data using the Kubelka-Munk equation $(\mathrm{F}(\mathrm{R}))$, which expresses the absorbance as a function of reflectance: $\mathrm{F}\left(\mathrm{R}_{\infty}\right)=\left(1-\mathrm{R}_{\infty}\right)^{2} /\left(2 \mathrm{R}_{\infty}\right)$, where $\mathrm{R}$ is the reflectance. ${ }^{[42]}$ The band gap energy can be estimated by the Tauc plots $\left[\mathrm{h} v \cdot \mathrm{F}\left(\mathrm{R}_{\infty}\right)\right]^{1 / \gamma}$ as a function of the photon energy $(h v)$, where $\gamma$ is equal to $1 / 2$ for direct 
transitions and 2 for indirect transitions. ${ }^{[43]}$ Using the direct fitting, the estimated band gaps energies are 1.47 and $2.04 \mathrm{eV}$, for the direct and indirect transitions, respectively Figure 4 (b). For this compound the gap energy is of indirect type because the absorption band used for the energy calculation is located outside the ultraviolet range $(430 \mathrm{~nm}) .{ }^{[44]}$ These interest values can be classified this material among the semiconductor which is required for applications in the photovoltaic field.

The estimated $E_{g}(\sim 2.04 \mathrm{eV})$ for compound (I) is comparable to those observed for recently reported two-dimensional (2D) hybrid halide perovskites such as $\left(\mathrm{C}_{6} \mathrm{H}_{5} \mathrm{CH}_{2} \mathrm{NH}_{3}\right)_{2} \mathrm{CuBr}_{4}\left(\mathrm{E}_{\mathrm{g}}=1.81\right.$ $\mathrm{eV}),{ }^{[22]}\left(\mathrm{CH}_{3} \mathrm{NH}_{3}\right)_{2} \mathrm{CuCl}_{2} \mathrm{Br}_{2}\left(\mathrm{E}_{\mathrm{g}}=2.12 \mathrm{eV}\right),\left(\mathrm{CH}_{3} \mathrm{NH}_{3}\right)_{2} \mathrm{CuCl}_{4}\left(\mathrm{E}_{\mathrm{g}}=2.48 \mathrm{eV}\right)^{[37]}$ and $\left(\mathrm{C}_{24} \mathrm{H}_{22} \mathrm{~N}_{2} \mathrm{O}_{3}\right) \mathrm{CuCl}_{4}\left(\mathrm{E}_{\mathrm{g}}=2.67 \mathrm{eV}\right)^{[38]}$.

\subsection{Real and imaginary permittivity}

The temperature dependences of the real and imaginary parts of dielectric permittivity and $\operatorname{tg} \delta$ of $\left(\mathrm{ClC}_{2} \mathrm{H}_{4} \mathrm{NH}_{3}\right)_{2} \mathrm{CuBr}_{4}$ compound (Figure 5 (a), (b) and (c)) at different frequencies show two anomalies at $\mathrm{T}_{1}=275 \mathrm{~K}$ and $\mathrm{T}_{2}=325 \mathrm{~K}$. These transitions are observed in DSC study with a temperature difference that is related to the error of calorimetric and electrical measuring devices. The higher values of real and imaginary parts of permittivity observed at low frequencies are due to integrated effect of all types of polarization such as the ion-ion orientations, ionic vibrations, space charge effects and electrode polarization. At higher frequencies, some polarization may not be effective, and dielectric constant is small as compared to values at low frequencies. ${ }^{[45-46]}$

\subsection{Impedance spectroscopy, equivalent circuit and conductivity}

The Nyquist diagram as a function of temperature is a mean to determinate the equivalent circuit, separate the contribution of grain and grain boundary and characterize the phase transitions by the variation of grain conductivity as a function of temperature. In this approach, we registered the Nyquist diagrams as a function of temperature and they are shown in Figure 6 (a), (b) and (c). The evolution shows three regions separated by the two transition temperatures $T_{1}$ and $T_{2}$ : the two regions in the $233-263 \mathrm{~K}$ and $333-403 \mathrm{~K}$ temperature ranges (Figure 6 (a) and (c)) show the decreasing resistivity with the increasing temperature that indicates the thermally activated conductivity. These regions are described by the same equivalent circuit (Figure 6 (d) and (f)) modeled by a series combination of three cells formed each by a parallel combination of a resistance and a C capacity or CPE fractal capacity. This circuit describes the contribution of the grains at higher frequencies, grain boundaries and the electrode effect at low frequencies. The other region over 273-313K (Figure 6 (b)) indicates that the resistivity increases with increasing temperature and it is a characteristic of a metallic conduction: when the temperature increases, the 
density of conduction electrons remains constant, but the thermal agitation increases the frequency of the collisions and thus decreases the conductivity. As a result, the conductivity of a metal decreases as the temperature increases. The equivalent circuit for this region (Figure 6 (e)) shows the overlap of the grain and grain boundaries by the cell $(\mathrm{R} / / \mathrm{C} / / \mathrm{CPE})$ and the electrode effect by the cell (R//CPE). Nyquist diagram similation shows the good conformity between the experimental and theoretical curves which allows determining the resistivity of the grain at each temperature. This value of resistivity is used to calculate the conductivity of the grain by the following relation:

$$
\sigma_{\mathrm{g}}=\mathrm{e} / \mathrm{RS}
$$

Where $\mathrm{R}$ is the resistivity, e and $\mathrm{S}$ are parameters which describe the geometry of the pellet.

The dependence of conductivity on temperature, as presented in Figure 7, shows a change of slope near the transitions $\mathrm{T}_{1}$ and $\mathrm{T}_{2}$ observed in the DSC study. The two regions, where the conductivity is thermally activated, are described by the Arrhenius law and the activation energies are equal to 0.27 and $0.05 \mathrm{eV}$ in the high and low temperature ranges, respectively. The low value of activation energy at room temperature $(0.05 \mathrm{eV})$ proves the semiconductor character of this material.

\section{Conclusion}

In conclusion, we have successfully synthesized a 2D copper based hybrid perovskite-like compound, $\left(\mathrm{ClC}_{2} \mathrm{H}_{4} \mathrm{NH}_{3}\right)_{2} \mathrm{CuBr}_{4}$, which undergoes a reversible phase transitions at around $\mathrm{T}_{1}=270 \mathrm{~K}$ and $\mathrm{T}_{2}=323 \mathrm{~K}$, as evidenced by DSC and electric measurements. The single-crystal Xray diffraction study reveals that the structural phase transition with symmetry breaking is mainly governed by an unusual chair-to-boat conformational transformation in the organic moiety and the distortion of $\mathrm{CuBr}_{6}$ inorganic chains. The large space enclosed by inorganic copper frameworks and the weak hydrogen-bonding interactions between the organic and inorganic components afford the freedom of the dynamic motions of the organic cations. It also displays semiconducting behavior with an optical band gap of $1.47 \mathrm{eV}$. Importantly, our study can offer some useful inspiration for the further development of halide perovskite phase transitions materials accompanied by excellent semiconducting properties.

\section{Conflicts of interest}

There are no conflicts to declare.

\section{Appendix}


The CCDC (Cambridge Crystallographic Data Centre) 1968437-1982704 for $\left(\mathrm{ClC}_{2} \mathrm{H}_{4} \mathrm{NH}_{3}\right)_{2} \mathrm{CuBr}_{4}$ (I) provides the supplementary crystallographic data for this manuscript, which can be accessed free of cost via www.ccdc.cam.ac.uk/structures.

\section{Acknowledgments}

The authors thank the University of Sfax-Tunisia for financial support and CDIFX (UMR 6226, Univ. Rennes 1) for X-ray diffraction data collections.

\section{References}

[1] (a) H. Kim, J. S. Han, S. G. Kim, S. Y. Kim and H. W. Jang, J. Mater. Chem. C, 2019, 7, 52265234 ; (b) L. K. Ono, E. J. Juarez-Perez and Y. Qi, ACS Appl. Mater. Interfaces, 2017, 9, 36, 30197-30246 ; (c) M. Wuttig and N. Yamada, Nat. Mater., 2007, 6, 824-832; (d) B. Saparov and D. B. Mitzi, Chem. Rev., 2016, 116, 4558-4596

[2] (a) H.-Y. Ye, Y.-Y. Tang, P.-F. Li, W.-Q. Liao, J.-X. Gao, X.-N. Hua, H. Cai, P.-P. Shi, Y.-M. You, R.-G. Xiong, , Science, 2018, 361, 151-155; (b) A. O. Polyakov, A. H. Arkenbout, J. Baas, G. R. Blake, A. Meetsma, A. Caretta, P. H. M. van Loosdrecht and T. T. M. Palstra, Chem. Mater., 2012, 24, 133-139; (c) L. Li, X. Liu, Y. Li, Z. Xu, Z. Wu, S. Han, K. Tao, M. Hong, J. Luo and Z. Sun, J. Am. Chem. Soc., 2019, 141, 2623-2629.

[3] (a) M. De Bastiani, M. I. Saidaminov, I. Dursun, L. Sinatra, W. Peng, U. Buttner, O. F. Mohammed and O. M. Bakr, Chem. Mater., 2017, 29, 3367-3370; (b) J. Lin, M. Lai, L. Dou, C. S. Kley, H. Chen, F. Peng, J. Sun, D. Lu, S. A. Hawks, C. Xie, F. Cui, A. P. Alivisatos, D. T. Limmer and P. Yang, Nat. Mater., 2018, 17, 261-267; (c) J. Li, X. Liu, P. Cui, J. Li, T. Ye, X. Wang, C. Zhang and Y. S. Zhao, Sci. China Chem., 2019, 62, 1257-1262.

[4] (a) A. Kumar Jena, A. Kulkarni and T. Miyasaka, Chem. Rev., 2019, 119, 3036-3103; (b) Q. Tai, K.-C. Tang and F. Yan, Energy Environ. Sci., 2019, 12, 2375-2405; (c) L. Meng, F. Zhang, W. Ma, Y. Zhao, P. Zhao, H. Fu, W. Wang, S. Meng, X. Guo, J. Phys. Chem. C, 2019, 123, 1219-1225. [5] (a) Q. Chen, N. De Marco, Y. Yang, T.-B. Song, C.-C. Chen, H. Zhao, Z. Hong, H. Zhou, Y. Yang, Nano today, 2015, 10, 355-396; (b) Z. Yi, N. H. Ladi, X. Shai, H. Li, Y. Shen and M. Wang, Nanoscale Adv., 2019, 1, 1276-1289 ; (c) K. Leng, I. Abdelwahab, I. Verzhbitskiy, M. Telychko, L.

Chu, W. Fu, X. Chi, N. Guo, Z. Chen, Z. Chen, C. Zhang, Q.-H. Xu, J. Lu, M. Chhowalla, G. Eda and K. P. Loh, Nat. Mater., 2018, 17, 908-914.

[6] K. Liu, Y. Jiang, Y. Jiang, Y. Guo, Y. Liu, E. Nakamura, J. Am. Chem. Soc., 2019, 141, 14061414. 
[7] (a) L. N. Quan, B. P. Rand, R. H. Friend, S. G. Mhaisalkar, T.-W. Lee and E. H. Sargent, Chem. Rev., 2019, 119, 7444-7477; (b) L. Zhao, Y.-W. Yeh, N. L. Tran, F. Wu, Z. Xiao, R. A. Kerner, Y. L. Lin, G. D. Scholes, N. Yao and B. P. Rand, ACS Nano, 2017, 11, 3957-3964.

[8] L. Theofylaktos, K. O. Kosmatos, E. Giannakaki, H. Kourti, D. Deligiannis, M. Konstantakoua and T. Stergiopoulos, Dalton Trans., 2019, 48, 9516-9537.

[9] G.Y. Kim, A. Senocrate, T.Y. Yang, G. Gregori, M. Grätzel, J. Maier, Nat. Mater., 2018, 17, 445-449.

[10] Q. Ye, H.-T. Wang, L. Zhou, L.-H. Kong, H.-Y. Ye, D.-W. Fu, Y. Zhang, Dalton Trans., 2016, 45, 1000-1006.

[11] Q. Li, P.-P. Shi, Q. Ye, H.-T. Wang, D.-H. Wu, H.-Y. Ye, D-W. Fu and Y. Zhang, Inorg. Chem., 2015, 54, 10642-10647.

[12] Z. Wang, X.-H. Lv, Y.-L. Liu, Y. Lu, H.-P. Chen and J.-Z. Ge, Inorg. Chem. Front., 2017, 4, 1330-1336.

[13] (a) J. Luo, T. Khan, M. A. Asghar, Z. Sun, A. Zeb, L. Li, L. Sijie, C. Ji, S. Zhao, Chem. Asian J., 2016, 11, 2876-2881 ; (b) Dr. C. Xue, S. Wang, W. $\square$ L. Liu and X. $\square$ M. Ren, Chem. Eur. J., 2019, 25, 5280-5287.

[14] X.-N. Hua, J.-X. Gao, X.-G. Chen, P.-F. Li, G.-Q. Mei and W.-Q. Liao, Dalton Trans., 2019, 48, 6621-6626

[15] S. Maheshwari, M. B. Fridriksson, S. Seal, J. Meyer and F. C. Grozema, J. Phys. Chem. C, 2019, 123, 14652-14661

[16] W. Zhang, Z. Sun, J. Zhang, S. Han, C. Ji, L. Li, M. Hong and J. Luo, J. Mater. Chem. C, 2017, 5, 9967-9971.

[17] K. Du, Q. Tu, X. Zhang, Q. Han, J. Liu, S. Zauscher and D. B. Mitz, Inorg. Chem., 2017, 56, 9291-9302.

[18] Y. Lu, Z. Wang, H.-P. Chen, J.-Z. Ge, CrystEngComm., 2017, 19, 1896-1901.

[19] (a) Z. X. Wang, W. Q. Liao, H. Y. Ye, Y. Zhang, Dalton Trans., 2015, 44, 20406-20412 ; (b)

J.-H. Lei, Y.-Q. Zhao, Q. Tang, J.-G. Lin and M.-Q. Cai, Phys Chem Chem Phys., 2018, 20, 1324113248.

[20] H.-Y. Ye, Q. Zhou, X. Niu, W.-Q. Liao, D.-W. Fu, Y. Zhang, Y.-M. You, J. Wang, Z.-N. Chen and R.-G. Xiong, J. Am. Chem. Soc., 2015, 137, 13148-13154.

[21] X.-H. Lv, W.-Q. Liao, P.-F. Li, Z.-X. Wang, C.-Y. Mao and Y. Zhang, J. Mater. Chem. C, 2016, 4, 1881-1885.

[22] X. Li, B. Li, J. Chang, B. Ding, S. Zheng, Y. Wu, J. Yang, G. Yang, X. Zhong and J. Wang, ACS Appl. Energy Mater., 2018, 1, 2709-2716.

[23] Q. Li, S. Li, K. Wang, Z. Quan, Y. Meng and B. Zou, J. Phys. Chem. Lett., 2017, 8, 500-506. 
[24] S. Gupta, T. Pandey and A. K. Singh, Inorg. Chem., 2016, 55, 6817-6824.

[25] X.-P. Cui, K.-J. Jiang, J.-H. Huang, Q.-Q. Zhang, M.-J. Su, L.-M. Yang, Y.-L. Song and X.-Q. Zhou, Synth. Met., 2015, 209, 247-250.

[26] APEX3 program suite V2016.1-0, Bruker AXS Inc., Wisconsin, USA.

[27] APEX2 program suite V2014.11-0, Bruker AXS Inc., Wisconsin, USA.

[28] G. M. Sheldrick, SAINT Version 8.37A, 2013, Bruker AXS Inc., Wisconsin, USA.

[29] G. M. Sheldrick, SADABS version 2014/5, SADABS Bruker AXS Inc., Madison, Wisconsin, USA.

[30] G. Sheldrick, Acta Crystallogr. A, 2015, 71, 3-8.

[31] G. Sheldrick, Acta Crystallogr. C, 2015, 71, 3-8.

[32] L. Farrugia, J. Appl. Cryst., 2012, 45, 849-854.

[33] W. T. Pennington, J. Appl. Crystallogr., 1999, 32, 1028-1029.

[34] X.-F. Sun, P.-F. Li, W.-Q. Liao, Z. Wang, J. Gao, H.-Y. Ye and Y. Zhang, Inorg. Chem., 2017, 56, 12193-12198.

[35] A. Sen, D. Swain, T. N. Guru Row and A. Sundaresan, J. Mater. Chem. C, 2019, 7, 4838-4845.

[36] H. $\square$ P. Chen, P. $\square$ P. Shi, Z. $\square$ X. Wang, J. $\square$ X. Gao, W. $\square$ Y. Zhang, C. Chen, Y. $\square$ Y. Tang and D $\square$ W. Fu, Dalton Trans., 2018, 47, 7005-7012.

[37] D. Cortecchia, H. A. Dewi, J. Yin, A. Bruno, S. Chen, T. Baikie, P. P. Boix, M. Gratzel, S. Mhaisalkar, C. Soci, N. Mathews, Inorg. Chem., 2016, 55, 1044-1052.

[38] D. Cortecchia, C. Soci, M. Cametti, A. Petrozza and J. Marti-Rujas, ChemPlusChem., 2016, 81, 1-6.

[39] Q. Li, S. Li, K. Wang, Z. Quan, Y. Meng and B. Zou, J. Phys. Chem. Lett., 2017, 8, 500-506.

[40] (a) G.S. Patrin, N.V. Volkov and I.V. Prokhorova, J. Magn. Mater., 2003, 131, 258-259 ; (b) S. E. Jang, M. J. Kim and A. R. Lim, AIP Adv., 2018, 8, 105324-105332.

[41] N. Mahfoudh, K. Karoui, M. Gargouri, A. BenRhaiem, Appl. Organometal. Chem., 2020, 34, 5404-5411.

[42] G. Kortum, W. Braun and G. Herzog, Angew. Chem. Int. Ed., 1963, 75, 653-661.

[43] J. Tauc, R. Grigorov and A. Vancu, Phys. Status Solidi B, 1966, 15, 627-637.

[44] Y. Sui, W.T. Chen, S. X. Ouyang, W.Q. Wang, G. X. Zhang and D.S. Liu, J. Phys. Chem.C, 2019, 123, 9364-9370.

[45] M. Ben Bechir, K. Karoui, M. Tabellout, K. Guidara, A. Ben Rhaiem, Phase Transit., 2015, 91, 901-917.

[46] F. Lambarki, A. Ouasri, A. Rhandour, M. Saadi, L. El Ammari, L. Hajji, J. Mol. Struct., 2018, 1173, 865-875. 


\section{Figures captions}

Figure 1. DSC curves of $\left(\mathrm{ClC}_{2} \mathrm{H}_{4} \mathrm{NH}_{3}\right)_{2} \mathrm{CuBr}_{4}$ at $5 \mathrm{~K} \mathrm{~min}^{-1}$.

Figure 2. Packing diagram of $\left(\mathrm{ClC}_{2} \mathrm{H}_{4} \mathrm{NH}_{3}\right)_{2} \mathrm{CuBr}_{4}$ (I) along the b-axis (a) at $150 \mathrm{~K}$ (LT phase), and (c) at $293 \mathrm{~K}$ (HT phase). The H-atoms of organic cation are emitted for clarity. Hydrogen-bonding interactions (blue and red dashed lines) between the organic and inorganic components in (I) at (b) $150 \mathrm{~K}$ and (d) $293 \mathrm{~K}$. (e) Description of the $2 \mathrm{D}$ perovskite network of (I) by the dimensional concept from the $\mathrm{CuBr}_{6}$ layers.

Figure 3. Comparaison on the degree of distortion of zigzag-inorganic chains at $150 \mathrm{~K}$ (LT phase) and $293 \mathrm{~K}$ (HT phase).

Figure 4. (a) UV-vis Absorption spectra and (b) the inset displays the Tauc plot deduced from the optical spectrum of $\left(\mathrm{ClC}_{2} \mathrm{H}_{4} \mathrm{NH}_{3}\right)_{2} \mathrm{CuBr}_{4}(\mathbf{I})$.

Figure 5. (a) Temperature dependence of the real, (b) imaginary part of dielectric permittivity and (c) $\operatorname{tg} \delta$ of $\left(\mathrm{ClC}_{2} \mathrm{H}_{4} \mathrm{NH}_{3}\right)_{2} \mathrm{CuBr}_{4}(\mathbf{I})$, at different frequencies.

Figure 6. a, b, c, d, e and f: Nyquist diagram spectra as a function of temperature with electrical equivalent circuit for $\left(\mathrm{ClC}_{2} \mathrm{H}_{4} \mathrm{NH}_{3}\right)_{2} \mathrm{CuBr}_{4}(\mathbf{I})$.

Figure 7. Variation of the $\mathrm{Ln}\left(\sigma_{\mathrm{g}}\right)$ versus $1000 / \mathrm{T}$ for $\left(\mathrm{ClC}_{2} \mathrm{H}_{4} \mathrm{NH}_{3}\right)_{2} \mathrm{CuBr}_{4}(\mathbf{I})$. 







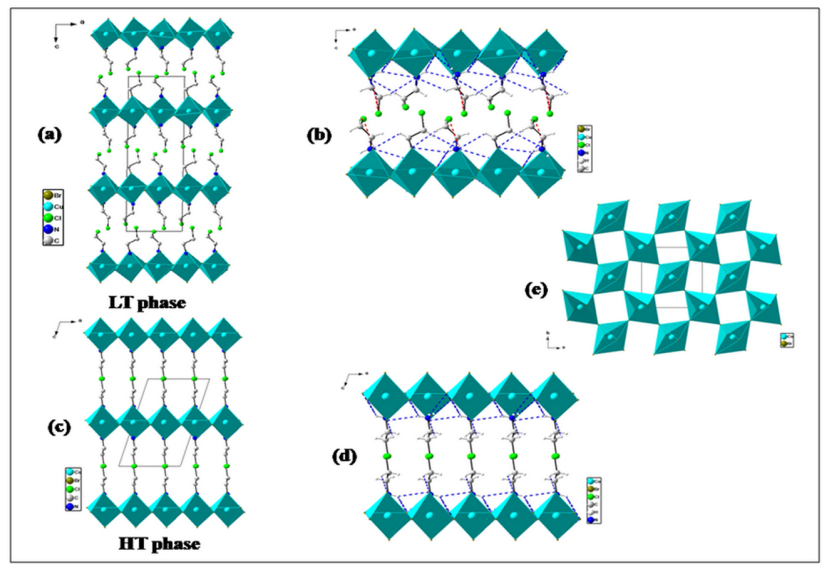

Figure 2. Packing diagram of $\left(\mathrm{ClC}_{2} \mathrm{H}_{4} \mathrm{NH}_{3}\right)_{2} \mathrm{CuBr}_{4}(\mathrm{I})$ along the $b$ axis (a) at $150 \mathrm{~K}$ ( $\mathrm{CT}$ phase), and (c) at $293 \mathrm{~K}$ (HT phase) The H atoms of organic cation are omitted for clarity. Hydrogen bonding interactions (blue and red dashed lines) between by the dimensional concept from the $\mathrm{CuBr}_{6}$ layers. 


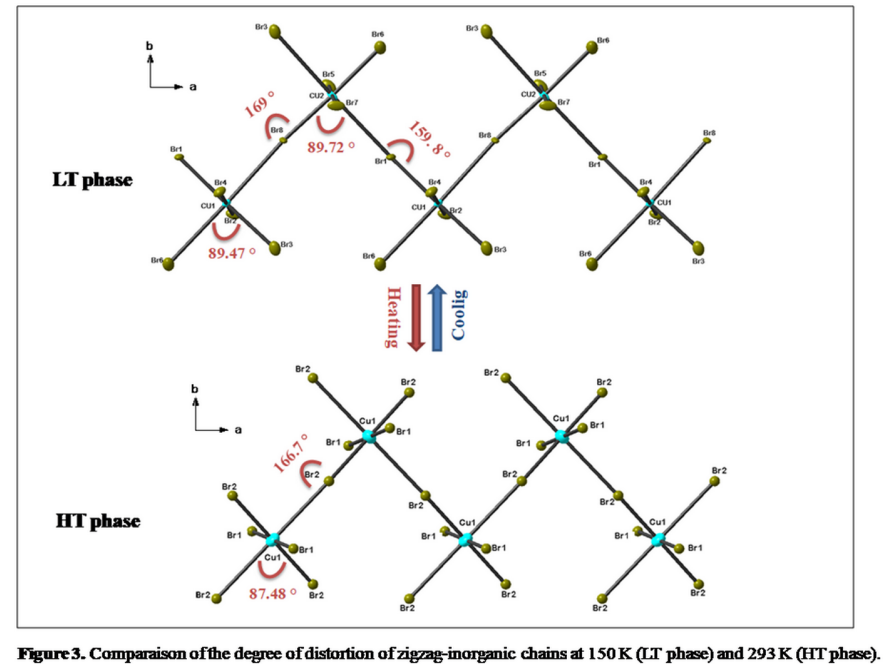




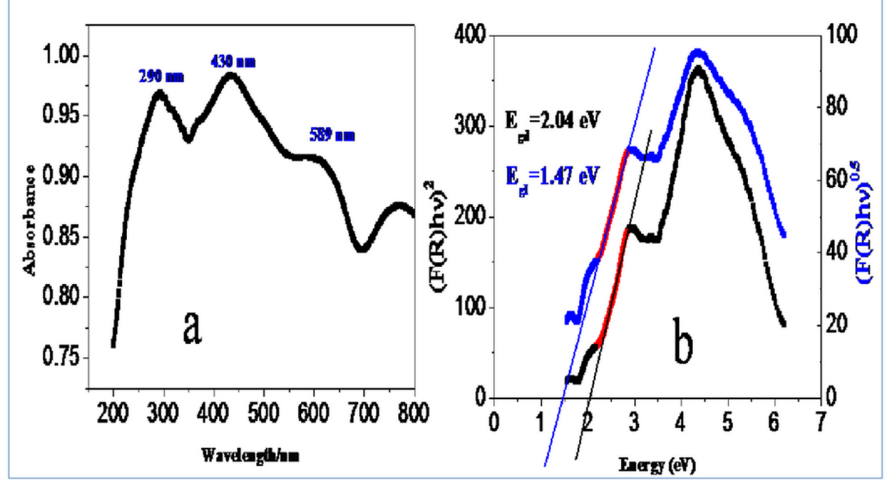

Figure 4. (a) UV-vis Absoption spectra of $\left(\mathrm{ClC}_{2} \mathrm{H}_{4} \mathrm{NH}_{3}\right)_{2} \mathrm{CuBr}_{4}(\mathbf{M})$. (b) Inset. Calculated band gap of $\left(\mathrm{ClC}_{2} \mathrm{H}_{4} \mathrm{NH}_{32} \mathrm{CuBB}_{4}(\mathfrak{l})\right.$. 


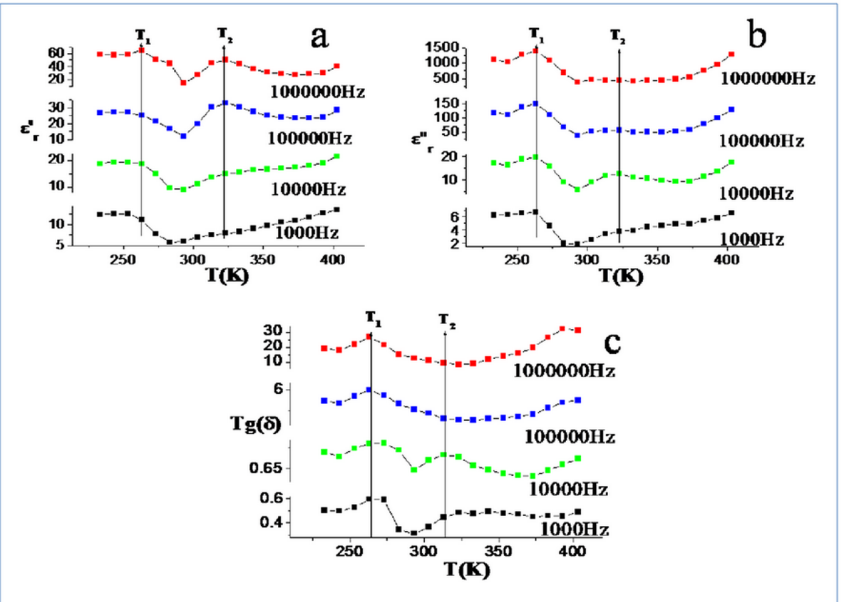

Figure 5. (a) Temperature dependence of the real, (b) imaginary part of dielectric permittivity and (c) tog of $\left(\mathrm{ClC}_{2} \mathrm{H}_{4} \mathrm{NH}_{3}\right)_{2} \mathrm{CnBr}_{4}(\mathbf{I})$, at different frequencies. 


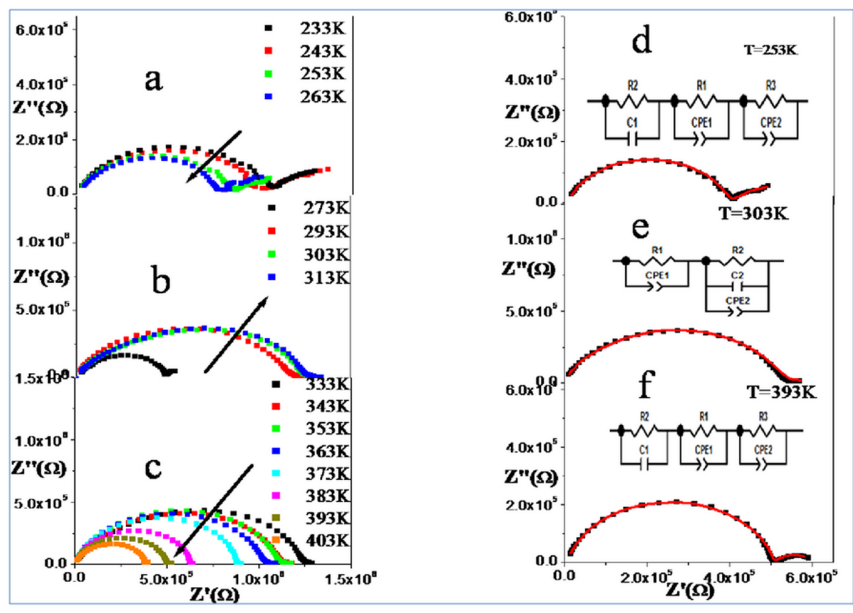

Figure 6. a, b, c, d, e and $\mathrm{f}$ Nyquist diagram spectra as a finction of temperature with electrical equivalent circoit for $\left(\mathrm{ClC}_{2} \mathrm{H}_{4} \mathrm{NH}_{3}\right)_{2} \mathrm{CuBr}_{4}(\mathbf{I})$. 




Figure 7. Variation of the $L n\left(\sigma_{8}\right)$ versus $1000 / \mathrm{T}$ for $\left(\mathrm{ClC}_{2} \mathrm{H}_{4} \mathrm{NH}_{3}\right)_{2} \mathrm{CuBr}_{4}(\mathrm{I})$. 


\section{AUTHOR DECLARATION}

1) We wish to confirm that there are no known conflicts of interest associated with this publication and there has been no significant financial support for this work that could have influenced its outcome.

2) We confirm that the manuscript has been read and approved by all named authors and that there are no other persons who satisfied the criteria for authorship but are not listed. We further confirm that the order of authors listed in the manuscript has been approved by all of us.

3) We confirm that neither the entire paper nor any of its content has been submitted, published, or accepted by another journal. The paper will not be submitted elsewhere if accepted for publication in the Journal.

4) We confirm that we have given due consideration to the protection of intellectual property associated with this work and that there are no impediments to publication, including the timing of publication, with respect to intellectual property. In so doing we confirm that we have followed the regulations of our institutions concerning intellectual property.

5) We confirm that any aspect of the work covered in this manuscript that has involved either experimental animals or human patients has been conducted with the ethical approval of all relevant bodies and that such approvals are acknowledged within the manuscript.

6) We understand that the Corresponding Author is the sole contact for the Editorial process (including Editorial Manager and direct communications with the office). He/she is responsible for communicating with the other authors about progress, submissions of revisions and final approval of proofs.

Signed by all authors as follows:

The submission of the manuscript has been approved by all co-authors.

Yours Faithfully,

Prof Fadhel Hajlaoui 